\title{
Constrictotermes cyphergaster (Blattaria, Termitidae) termite nests as substrates for lichen fixation in the semiarid region of northeastern Brazil
}

\author{
A. M. Barbosa-Silva ${ }^{a *}$ (D), L. A. Santos ${ }^{b}$ (D), M. E. S. Cáceres ${ }^{\text {(D) }}$ and A. Vasconcellos ${ }^{a}$ \\ aDepartamento de Sistemática e Ecologia, Universidade Federal da Paraíba - UFPB, Cidade Universitária, s/n, Castelo \\ Branco, CEP 58051-900, João Pessoa, PB, Brasil \\ ${ }^{\text {b}}$ Departamento de Micologia, Universidade Federal de Pernambuco - UFPE, Avenida Prof. Moraes Rego, 1235, Cidade \\ Universitária, CEP 50740-600, Recife, PE, Brasil \\ 'Departamento de Biociências, Universidade Federal de Sergipe - UFS, Avenida Vereador Olímpio Grande, s/n, Porto, \\ Centro, CEP 49500-000, Itabaiana, SE, Brasil \\ *anamarcia1983@hotmail.com
}

Received: April 8, 2019 - Accepted: June 19, 2019 - Distributed: August 31, 2020

(With 1 figure)

Termite nests are natural environments rich in organic material, and therefore favorable to the growth of a variety of microorganisms (Sands, 1969; Siebers et al., 2015). Aptroot and Cáceres (2014) described four new lichen species growing on termite mounds in a humid tropical forest area in the Amazon region of Brazil. Other lichens associated with termite nests in subtropical areas of Brazil have been identified, including Buellia termitum Vain (Vainio, 1980), B. termitophila Malme (Malme 1928), and Lecidea termitophila Malme (Malme 1936). Similar records for lichens growing on termite nests in semiarid ecosystems have not yet, however, been published. This study records the presence of lichenized ascomycetes associated with the nests of Constrictotermes cyphergaster (Silvestri 1901) (Termitidae, Nasutitermitinae) in a semiarid ecosystem in northeastern Brazil.

The present study was undertaken at Fazenda Almas Private Natural Heritage Reserve (RPPN) (07 28'S; $\left.36^{\circ} 52^{\prime} \mathrm{W}\right)$, located in an area of Caatinga (thorny, deciduous, dryland) vegetation in Paraíba State, northeastern Brazil. The RPPN occupies an area of approximately 3.505 ha. The region has a mean total annual precipitation of $560 \pm 230 \mathrm{~mm}$; and mean annual temperature and humidity of $25.8^{\circ} \mathrm{C}$ and $65 \%$ respectively (Núcleo de Meteorologia Aplicada, 1987).

The outer surface of 18 active nests, with volumes between 18 and 38 liters, distant from each other for at least $10 \mathrm{~m}$, were examined in the field using a hand-held magnifying lens $(12 x)$. The observations were made in august 2017 and the lichens identified on the surface of the nests were then collected and stored in paper sacks for subsequent species identifications in the laboratory, following Aptroot (1988), McCarthy (1991), Cáceres (2007). Lichen richness was given based on the total number of species encountered on the nests; their abundances were determined by direct counting of their thalli on that substrate. Means and standard deviations of lichen abundances were calculated to determine variations in the occurrences of the different species.

Seven lichens species were found on the surface of the termite nests: Caloplaca subsoluta (Nyl.) Zahlbr
(Mean $3.77 \pm \mathrm{SD}$ 6.06); Caloplaca sp. (4.77 \pm 7.02); Sculptolumina japonica (Tuck.) Marbach (1.05 \pm 2.23 ); Amandinea errata Marbach (1.50 \pm 2.20$)$; Endocarpon pallidellum Ach (0.72 \pm 1.59$)$; Dirinaria aplanata (Fee) D. D. Awasthi $(0.11 \pm 0.32)$; and Hyperphyscia adglutinata (Florke) H. Mayrh. and Poelt (0.16 \pm 0.51$)$ (Fig. 1).

Lichens grow on a wide variety of natural and artificial substrates (Brodo et al., 2001), and the texture, humidity, and nutritional quality of those surfaces are important criteria for lichen thalli establishment (Nash, 2008). Expected that rough surfaces of termite nests could facilitate lichen establishment and development while the availability of humidity and organic material make them favorable environments for lichen growth.

Lichen dispersion is mainly by wind, rain or exozoocoria (Nash, 2008). It is possible that the consumption of lichen stems by C. cyphergaster (Barbosa-Silva et al., 2019) may promote dispersal of lichens in termite nests, either through propagules that accidentally impregnate their bodies during consumption, or by feces deposition in the nest structure, which may contain viable reproductive cells to form new lichen thalli. However, the dispersal of lichens by termites still needs to be evaluated.

Termites repair and increase the sizes of their nests by adding fresh material to construct new cells - resulting in constant renovations of their exterior layers. As lichens demonstrate only slow growth, their greatest occurrences are found on the surfaces of more mature nests. For that reason, they were only found on nests with volumes that were greater than $30 \mathrm{~L}$.

The present study represents the first records of lichenized fungi on termite nests in a semiarid ecosystem in Brazil, with emphasis on the nests of C. cyphergaster. We highlight that species of Caloplaca (Figure 1), common rock lichens, seem to find in the termite nests a favorable environment for fixation and growth. Abandoned nests of $C$. cyphergaster should contain a wealth of lichens differentiated from that observed in this study, being an interesting recommendation for future investigations. 

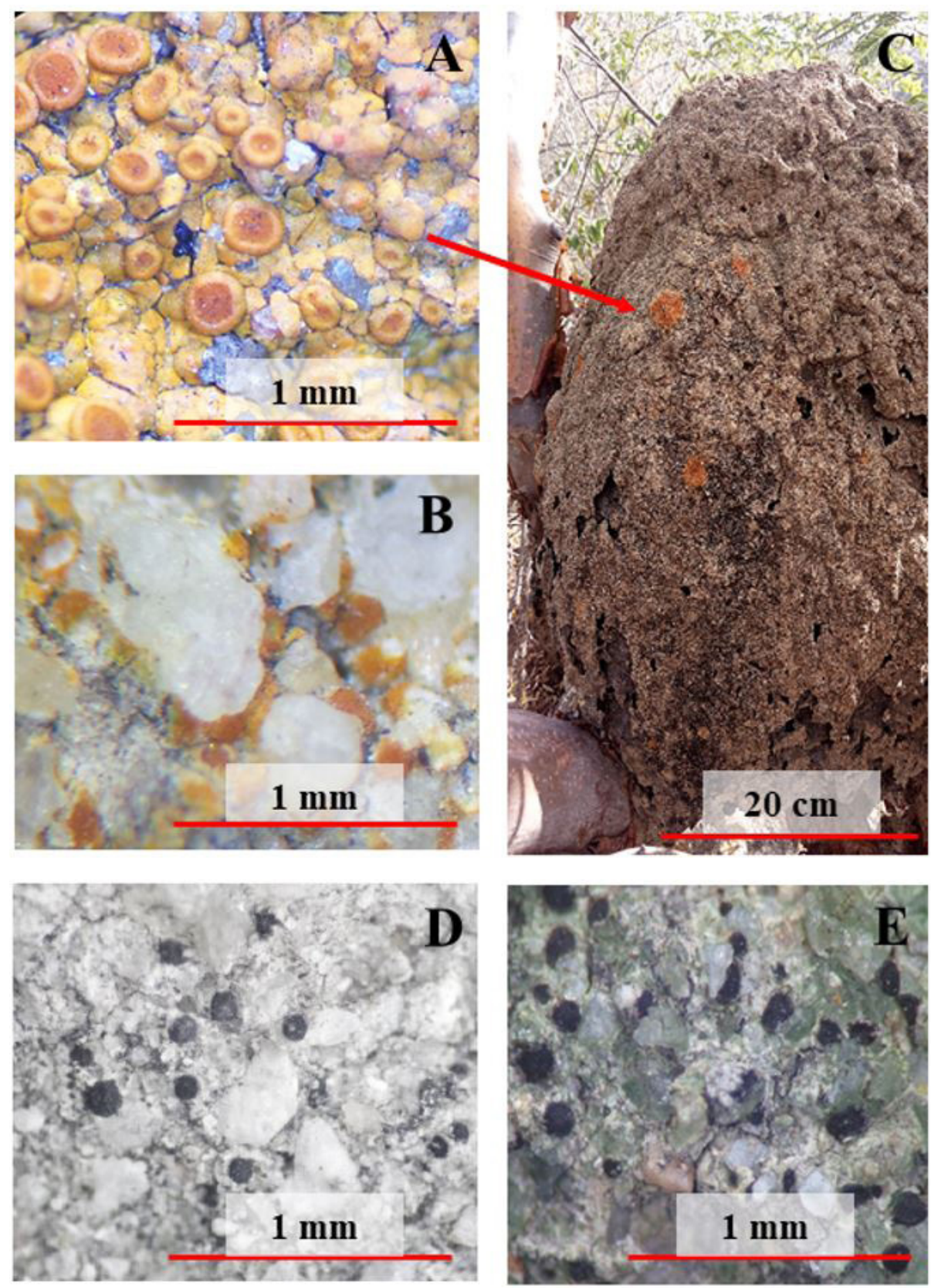

Figure 1. Lichens growing on the surfaces of Constrictotermes cyphergaster termite nests in the semiarid region of northeastern Brazil. A- Caloplaca subsoluta; B- Caloplaca sp; C- Species of Caloplaca on a C. cyphergaster termite nest; D- Amandinea errata; E- Sculptolumina japonica.

\section{Acknowledgements}

The authors thank CNPq - The National Council for Scientific and Technological Development for the productivity fellowship grants awarded to MESC and AV. Dr. André Aptroot is warmly thanked for the confirmation of the lichen species.

\section{References}

APTROOT, A. and CÁCERES, M.E.S., 2014. New lichen species from termite nests in rainforest in Brazilian Rondônia and adjacent Amazonas. Lichenologist, vol. 46, no. 3, pp. 365-372. http://dx.doi.org/10.1017/S0024282913000340.

APTROOT, A., 1988. Pyxinaceae (Lichens). Koenigstein: E. Koeltz Scientific Books, 206 p. Flora of the Guianas Series. 
BARBOSA-SILVA, A.M., SILVA, A.C., PEREIRA, E.C.G., BURIL, M.L.L., SILVA, N.H., CÁCERES, M.E.S., APTROOT, A. and BEZERRA-GUSMÃO, M.A., 2019. Lichen richness consumed by Constrictotermes cyphergaster in semi-arid region of Brazil. Sociobiology, vol. 66, no. 1, pp. 154-160. http://dx.doi. org/10.13102/sociobiology.v66i1.3665.

BRODO, I.M., SHARNOFF, S.D. and SHARNOFF, S., 2001. Lichens of North America. New Haven: Yale University Press, 795 p.

CÁCERES, M.E.S. 2007. Corticolous crustose and microfoliose lichens of northeastern Brazil. Eching: IHW-Verlag, 168 p. Libri Botanici, no. 22.

MALME, G.O.A., 1928. Buelliae itineris Regnelliani. Arkiv för Botanik, vol. 1, pp. 1-42.

MALME, G.O.A., 1936. Lecideae expeditionis Regnellianae primae. Arkiv för Botanik, vol. 28, pp. 1-53.

MCCARTHY, P.M., 1991. The lichen genus Endocarpon Hedwig in Australia. Lichenologist, vol. 23, no. 1, pp. 27-52. http://dx.doi. org/10.1017/S0024282991000087.
NASH, T.H. 3rd., 2008. Lichen Biology, Cambridge: Cambridge University Press, 498 p. http://dx.doi.org/10.1017/CBO9780511790478.

NÚCLEO DE METEOROLOGIA APLICADA, 1987. Atlas climatológico da Paraíba. Campina Grande: Universidade Federal da Paraíba, 143 p.

SANDS, W.A., 1969. The association of termites and fungi. In: K. KRISHNA and F.M. WEESNER, eds. Biology of termites. New York: Academic Press. pp. 495-524. http://dx.doi.org/10.1016/ B978-0-12-395529-6.50020-9.

SIEBERS, N., MARTIUS, C., ECKHARDT, K.U., GARCIA, M.V.B., LEINWEBER, P. and AMELUNG, W., 2015. Origin and alteration of organic matter in termite mounds from different feeding guilds of the Amazon Rainforests. PLoS One, vol. 10, no. 7, pp. e0123790. http://dx.doi.org/10.1371/journal.pone.0123790. PMid:25909987.

VAINIO, E.A., 1980. Estude sur la classification naturelle et la morphologie des lichens du Bresil. Acta Societatis Pro Fauna et Flora Fennica, vol. 7, pp. 247-256. 